\title{
Mapping of Food Security Based on Aspects of Food Access and Availability of Rice in Ogan Komering Ulu District
}

\author{
Fifian Permata Sari*, Munajat Munajat \\ Dept. of Agribusiness, Agriculture Faculty \\ University of Baturaja \\ Baturaja City, Indonesia \\ *fifianpermatasari@unbara.ac.id, munajat@unbara.ac.id
}

\begin{abstract}
Food security is understood as a system that concerns the availability of food, access to food and food consumption that is reflected in food supply, people's access to food, and the utilization of food products. The aim of this study was to analyze food access and rice availability in Ogan Komering Ulu District. The research method was quantitative descriptive, the data used in the study was secondary data obtained from the Ogan Komering Ulu District Agriculture Office, Statistics Agency, and related agencies. The results showed that in terms of rice availability, there were four districts which constitute a surplus of rice, and nine districts that constitute a rice deficit. The conclusion of this research, that there were seven districts that included in bad access were Lengkiti, Pengandonan, Muara Jaya, Semidang Aji, Ulu Ogan, Lubuk Batang, and Kedaton Raya District. While the relative conditions of combined availability of rice and its access to rice showed that there was one district which was included in a safe position, was West Baturaja district, while there were eight other districts which are included in alert condition.
\end{abstract}

Keywords: mapping, food security, food access

\section{INTRODUCTION}

Mapping is an efficient and effective way to determine land characteristics and their development potential in determining land suitability classes in an area and food security is understood as a system that concerns the availability of food, access to food and food consumption that is reflected in food supply, people's access to food, and the utilization of food products [1]. Food security is a condition in which people can feed themselves. Therefore, as a first step to address the problem of food insecurity, a need to identify food security conditions [2]. Food availability is expressed by all efforts for food production, access is implemented by creating a marketing flow system, and consumption is pursued with policies regarding the rules concerning nutritional value and food safety [3]. Food security and food self-sufficiency at household level are much determined by their farm production. Meanwhile, some areas considered as the marginal area are constrained by limited support of natural resources. Thus, many households lived in marginal area will face food insecurity [4]. Food security based on Law No. 18 of 2012, was a condition of the fulfillment of food needs for the country up to individuals as reflected by the availability of sufficient food, both in quantity and quality, safe, diverse, nutritious, equitable and affordable and not contrary to religion, beliefs, and culture of the community, for live healthy, active and productive in a sustainable manner [5]. Even and affordable are included in the aspect of food access. Where, evenly, namely that food is guaranteed for distribution evenly to each region so that food is easily obtained by the community and affordable, that is, food is possible to be obtained by the community easily and at reasonable prices [6].

Aspects of food access can be seen with the distribution of income, purchasing power, food prices and food expenditure. Food prices in Indonesia are still volatile. The issue of food prices becomes a sensitive matter, because if prices are high then people cannot access food, on the contrary if food prices are low then farmers can be disadvantaged. The Central Statistics Agency noted that the main expenditure of the Indonesian people was still on food. Based on the BPS Susenas in September 2015, the rural population spent 57.28 percent for food consumption, while 42.72 percent was used for non-food consumption [7]. Food security has a negative relationship with food expenditure. So, the greater the food expenditure of a household, the lower the food security of the household [8]. Furthermore, food utilization is related to how food consumed contains good nutrition and benefits for individual health. Food utilization is measured through the ability to meet energy and nutritional needs which can be seen from the Nutrition Adequacy Rate (RDA).

Food access is a subsystem in food security. This subsystem is an intermediate subsystem connecting the availability subsystem and the food absorption subsystem. Without food access, food security will not be achieved [9]. Food may be physically available in an area, but it cannot be accessed by certain households due to its limitations: i) physical access: market infrastructure, access to reach markets, and market functions, ii) economic access: financial ability to buy adequate and nutritious food, social access: and social capital that can be used to obtain internal support mechanisms such as bartering, borrowing or having a support program. 
Food security in Indonesia is classified as adequate nationally when seen from the availability side, but not from the access side. Access conditions can be seen from the high income inequality, low purchasing power, fluctuating food prices and high food expenditure. That means, despite the availability of abundant food, but the food is not accessible to all citizens. So access is one important element in food security, because access is a link between food availability and food absorption. If availability is not supported by access, the community cannot use food optimally, and therefore food security will not be achieved [6]. Food production centers in South Sumatra include the districts of East OKU, OKI, Musirawas, and Banyuasin. Food production in OKU Regency over the past five years has experienced ups and downs in terms of production. For lowland rice is the highest commodity in terms of production in 2017 was 48.419 tons. Rice Production in Ogan Komering Ulu Regency can be seen in Table 1 below,

TABLE I. RICE PRODUCTION IN OKU, 2013-2017

\begin{tabular}{|l|c|c|c|c|c|}
\hline \multirow{2}{*}{$\begin{array}{c}\text { Type of } \\
\text { food }\end{array}$} & \multicolumn{5}{|c|}{ Production (ton) } \\
\cline { 2 - 6 } $\begin{array}{l}\text { Lowland } \\
\text { rice }\end{array}$ & 45.988 & 53.783 & 44.145 & 51.041 & 48.419 \\
\hline $\begin{array}{l}\text { Paddy } \\
\text { rice }\end{array}$ & 20.881 & 18.118 & 15.854 & 15.127 & 10.991 \\
\hline Amount & 66.869 & 71.901 & 60.000 & 66.186 & 59.410 \\
\hline
\end{tabular}

Table 1 shows that there is a decrease in the number of farmers and paddy farmers in 2013 to 2017.The food supply crisis is a big and sensitive issue because of the increasingly high prices of food, especially rice since the global climate change and the incessant conversion of productive land into oil palm and rubber, including those in Ogan Komering Ulu District.

The availability of rice at a macro level does not guarantee the availability of micro rice. Production that only occurs in certain regions and at certain times causes a concentration of availability in the production areas and at harvest periods. The relative consumption patterns between individuals, between time and between regions have resulted in periods of deficit and locations of deficit in rice. So that market mechanisms and distribution of rice between locations and between times by relying on stock will affect the balance between availability and consumption and the prices that occur in the market. The price factor is strongly related to household purchasing power for food. Thus, even though food commodities are available in the market, if the price is high while the purchasing power of the household will cause the household to not be able to access it [5]. This condition triggers food insecurity. Food insecurity conditions make it necessary to map access to food, especially in Ogan Komering Ulu. Based on the description above, this study aims to analyzing food access and the availability of rice at the sub-district level in Ogan Komering Ulu District.

\section{RESEARCH METHODS}

This research was a quantitative descriptive using secondary data. Data in this study were obtained from the Ogan
Komering Ulu District Agriculture Office, the Central Statistics Agency of Ogan Komering Ulu District, and other relevant agencies. This research was conducted in 13 Districts in Ogan Komering Ulu. The site selection was done purposively on the basis of the consideration that the region had a tendency for food shortages to meet the needs of its population, given its relationship with its availability and access to food, because Ogan Komering Ulu was largely a rained area to produce rice food commodities, because most of the land is used for estate crops, housing and so on outside of rice. This research was conducted from November 2018 to January 2019.

Access to food is analyzed by changing all the indicators used into index form to standardize on a scale of 0 to 1 . Rice Access Index Seen from Economic and Income (IFLA)The indicators used are as follows [10], percentage of population living below the poverty line (IBPL), head of household who works less than 15 hours per week (ILAB), and percentage of household heads who did not complete basic education (IEDU). The three indicators above are converted into indexes on a scale of 0 to 1 which will produce a combined index of access to rice and income.

$$
\text { IFLA=1/3(IBPL+ILAB+IEDU) }
$$

Information:

IFLA $=$ Combined Index of Rice and Income Access

IBPL $=$ Population Index Below the Poverty Line

ILAB $=$ Index $\%$ of working population less than 15 hours / in a week

IEDU $=$ Index of Population Not Completing Basic Education

If the IFLA value is less than 1 (one), then the area of access to rice and income can be met in the area. And if the value of IFLA is more than 1 (one), then this shows the condition of access to rice and income cannot be met in the area.

Analysis of rice availability is carried out using the following equations:

\section{A. Net Rice Production} [11]:

Net rice production is calculated based on the following

Rnet $=\mathrm{c} *$ Pnet.

Where:

Pnet $=\mathrm{P} *\{1-(\mathrm{s}+\mathrm{w})\}$

Information:

Rnet $=$ Net Production of Rice

Pnet $=$ Net Rice Availability

$\mathrm{C}=$ Conversion Factor $(0.65)$

$\mathrm{P}=$ Rice Production for a Sub district

$\mathrm{S}=$ Conversion Value for Seedlings (0.009)

$\mathrm{W}=$ Conversion Value for Scattered $(0.054)$

In research only analyzing rice, Pfood is the net production of rice in the area (Rnet)

Pfood $=$ Rnet 
The availability of per capita rice per day $(\mathrm{F})$ is calculated by dividing the total net production of rice per total population of the sub-district to find out the average rice availability as follows [12]:

$$
\mathrm{F}=\mathrm{Pfood} / \mathrm{t}_{\mathrm{pop}}{ }^{* 365} \text {. }
$$

Information:

$\mathrm{F}=$ Availability of rice food per capita per day (grams) tpop $=$ Total sub-district population in the same year with rice food production data.

\section{B. Rice Availability Ratio}

$$
\mathrm{IAV}=\mathrm{Cnorm} / \mathrm{F} \text {. }
$$

Information:

IAV = Rice Availability Ratio

Cnorm $=$ Normal Consumption (300gram)

$\mathrm{F}=$ Availability of Rice Food.

If the IAV value is more than 1 (one), then the region has a rice food deficit or consumption needs cannot be met from the net production of rice available in the area. And if the IAV value is less than 1 (one), then this shows the condition of rice food surplus in the area.

Composite Index is used this calculation to find out the comparison that shows the change in values for different time periods [13]. With the calculation as follows:

$\mathrm{I}=$ Year now/early year

\section{RESULTS AND DISCUSSION}

\section{A. Rice Availability Analysis}

The availability of rice in Ogan Komering Ulu is based on rice production in Ogan Komering Ulu District in recent years which tends to be unstable. The availability of rice has a direct role in meeting people's consumption needs seen from an analysis of rice food availability:

1) Production of rice netto: Ogan Komering Ulu District is still relying on several districts that are already known as rice production centers such as the Providing District,
Semidang Aji District, and Ulu Ogan District. The rice production of these 3 districts is very dominant compared to other districts in Ogan Komering Ulu district. The analysis of rice production in Ogan Komering Ulu district based on the research results can be seen in the following Table 2 below :

TABle II. The ANALysis of Rice Production IN OGAN Komering ULU DISTRICT, 2013-2017

\begin{tabular}{|l|l|l|l|l|l|l|}
\hline \multirow{2}{*}{ No } & \multirow{2}{*}{ District } & \multicolumn{5}{|c|}{ Production of rice netto } \\
\cline { 3 - 7 } & & $\mathbf{2 0 1 3}$ & $\mathbf{2 0 1 4}$ & $\mathbf{2 0 1 5}$ & $\mathbf{2 0 1 6}$ & $\mathbf{2 0 1 7}$ \\
\hline 1 & Lengkiti & $2.314,9$ & 2.643 & 2.669 & 2.649 & 1.241 \\
\hline 2 & $\begin{array}{l}\text { Sosoh Buay } \\
\text { Rayap }\end{array}$ & $1.517,1$ & 1.284 & 1.423 & 1.109 & 939 \\
\hline 3 & Pengandonan & $9.431,1$ & 10.623 & 9.442 & 8.944 & 10.399 \\
\hline 4 & Semidang Aji & 7.212 & 8.903 & 7.799 & 8.449 & 5.358 \\
\hline 5 & Ulu Ogan & 4.723 & 8.857 & 4.252 & 4.399 & 6.237 \\
\hline 6 & Muara Jaya & 5.726 & 5.593 & 4.302 & 5.410 & 5.827 \\
\hline 7 & Peninjauan & 2.438 & 1.356 & 1.560 & 125 & 210 \\
\hline 8 & Lubuk Batang & 985 & 920 & 645 & 1.171 & 1.409 \\
\hline 9 & Sinar Peninjauan & 2.668 & 1.770 & 2.407 & 2.273 & 1.336 \\
\hline 10 & $\begin{array}{l}\text { Kedaton } \\
\text { Peninjauan Ray }\end{array}$ & - & - & - & 1.909 & 1.066 \\
\hline 11 & Baturaja Timur & 2.703 & 1.027 & 663 & 1.756 & 570 \\
\hline 12 & Baturaja Barat & 294 & 233 & 634 & 867 & 529 \\
\hline 13 & Lubuk Raja & 709 & 576 & 739 & 1.231 & 445 \\
\hline Amount & $40.726,5$ & 43.791, & 36.54 & $40.299,6$ & $35.574,6$ \\
\hline
\end{tabular}

Table 2 showed that the net rice production in Ogan Komering Ulu is unstable, this is influenced by several factors, namely: decreasing rainfall, decreasing productivity of farmers in producing rice and decreasing paddy fields due to land conversion such as Sosoh Buay Rayap, Lubuk Batang, etc. that should have government policies in the form of a Regional Regulation as a derivative of Law No. 41 of 2009 concerning the protection of sustainable agricultural land [14].

\section{B. Availability of Rice}

Rice is a staple food whose existence cannot be replaced until now. If this condition occurs continuously for decades, it is feared that conditions will be created where the existing rice production cannot meet the demands of public consumption. The research result of the availability of rice in some district of Ogan Komering Ulu shown in table 3.

TABLE III. ThE ANALYSIS OF RICE AVAILABILITY IN OKU DisTRICT, 2013-2017

\begin{tabular}{|l|l|l|l|l|l|l|}
\hline \multirow{2}{*}{ No District } & \multicolumn{5}{|c|}{ Rice availability } \\
\cline { 3 - 7 } & & \multicolumn{1}{|c|}{$\mathbf{2 0 1 3}$} & \multicolumn{1}{|c|}{$\mathbf{2 0 1 4}$} & \multicolumn{1}{|c|}{$\mathbf{2 0 1 5}$} & $\mathbf{2 0 1 6}$ & $\mathbf{2 0 1 7}$ \\
\hline 1 & Lengkiti & 0,000241 & 0,00027 & 0,000 & 0,00026 & 0,00012 \\
\hline 2 & Sosoh Buay Rayap & 0,000334 & 0,00028 & 0,000 & 0,00023 & 0,00019 \\
\hline 3 & Pengandonan & 0,002756 & 0,00308 & 0,002 & 0,00247 & 0,00283 \\
\hline 4 & Semidang Aji & 0,000766 & 0,00093 & 0,000 & 0,00247 & 0,00283 \\
\hline 5 & Ulu Ogan & 0,001422 & 0,00263 & 0,001 & 0,00085 & 0,00053 \\
\hline 6 & Muara Jaya & 0,002279 & 0,00220 & 0,001 & 0,00126 & 0,00177 \\
\hline 7 & Peninjauan & 0,000158 & $8,7 \mathrm{E}-05$ & $9.86 \mathrm{E}-05$ & 0,00204 & 0,00217 \\
\hline 8 & Lubuk Batang & $9,38 \mathrm{E}-05$ & $8,69 \mathrm{E}-05$ & $6,02 \mathrm{E}-05$ & $1.1 \mathrm{E}-05$ & $1,8 \mathrm{E}-05$ \\
\hline 9 & Sinar Peninjauan & 0,000333 & 0,00021 & 0,000 & 0,00010 & 0,00012 \\
\hline 10 & Kedaton Peninjauan Raya & - & - & - & 0,00042 & 0,00023 \\
\hline 11 & Baturaja Timur & $7,67 \mathrm{E}-05$ & $2,9 \mathrm{E}-05$ & $1.85 \mathrm{E}-05$ & $4.86 \mathrm{E}-05$ & $1,56 \mathrm{E}$ \\
\hline 12 & Baturaja Barat & $2.41 \mathrm{E}-05$ & $1,9 \mathrm{E}-05$ & $5,08 \mathrm{E}-05$ & $6,78 \mathrm{E}-05$ & $4,09 \mathrm{E}$ \\
\hline 13 & Lubuk Raja & $6,65 \mathrm{E}-05$ & $5.37 \mathrm{E}-05$ & $6,8 \mathrm{E}-05$ & 0,00011 & $4,01 \mathrm{E}$ \\
\hline Amount & 0,008549 & 0,00991 & 0,018 & 0,00818 & 0,00827 \\
\hline
\end{tabular}

Source: Processed secondary data, 2018. 
The high rice production in the regions does not guarantee the high availability of rice. This is caused by several factors including the amount of rice that has been consumed, and rice imports by other regions that are used to meet the burden of the amount of consumption. The condition of rice food security in each district in this study was obtained from the calculation of normative consumption per capita of 300 grams for the availability of rice. This result is consistent with finding from $[4,12,15]$. The composite index with the relative condition in OKU can be seen in Table 4 below:

TABLE IV. THE COMPOSIT INDEX AND RELATIVITY CONDITION

\begin{tabular}{|l|l|l|l|}
\hline No & \multicolumn{1}{|c|}{ District } & $\begin{array}{c}\text { Composite } \\
\text { index }\end{array}$ & $\begin{array}{l}\text { Relativity } \\
\text { condition }\end{array}$ \\
\hline 1 & Lengkiti & 1,00 & Not good \\
\hline 2 & Sosoh Buay Rayap & 0,91 & Good \\
\hline 3 & Pengandonan & 1,31 & Not good \\
\hline 4 & Semidang Aji & 1,03 & Not good \\
\hline 5 & Ulu Ogan & 1,03 & Not good \\
\hline 6 & Muara Jaya & 1,03 & Not good \\
\hline 7 & Peninjauan & 0,78 & Good \\
\hline 8 & Lubuk Batang & 1,04 & Not good \\
\hline 9 & Sinar Peninjauan & 0,96 & Good \\
\hline 10 & Kedaton Peninjauan Raya & 1,00 & Not good \\
\hline 11 & Baturaja Timur & 0,92 & Good \\
\hline 12 & Baturaja Barat & 0,87 & Good \\
\hline 13 & Lubuk Raja & 0,96 & Good \\
\hline
\end{tabular}

C. Combined Availability of Rice and Access to Rice

This relative condition of combined availability and access to rice is to find out which Districts were included in the safe, alert and unsafe condition of rice. The relative conditions of combined availability and access to rice at the District level in Ogan Komering Ulu Regency can be seen how the conditions of rice availability and access in each District in Ogan Komering Ulu District can be seen in Table 5 below:

TABLE V. ANALYSIS OF THE RELATIVE CONDITIONS AND ITS POSITION

\begin{tabular}{|l|l|l|l|l|}
\hline No & \multicolumn{1}{|c|}{ District } & $\begin{array}{c}\text { Condition } \\
\text { of relative } \\
\text { availability }\end{array}$ & $\begin{array}{c}\text { Condition } \\
\text { of access }\end{array}$ & Position \\
\hline 1 & Lengkiti & Deficit & Not good & Not safe \\
\hline 2 & Sosoh Buay Rayap & Deficit & Good & Alert \\
\hline 3 & Pengandonan & Surplus & Not good & Alert \\
\hline 4 & Semidang Aji & Deficit & Not good & Not safe \\
\hline 5 & Ulu Ogan & Surplus & Not good & Alert \\
\hline 6 & Muara Jaya & Deficit & Not good & Not safe \\
\hline 7 & Peninjauan & Deficit & Good & Alert \\
\hline 8 & Lubuk Batang & Surplus & Not good & Alert \\
\hline 9 & Sinar Peninjauan & Deficit & Good & Alert \\
\hline 10 & Kedaton Peninjauan Raya & Deficit & Not good & Not safe \\
\hline 11 & Baturaja Timur & Deficit & Good & Alert \\
\hline 12 & Baturaja Barat & Surplus & Good & Safe \\
\hline 13 & Lubuk Raja & Deficit & Good & Alert \\
\hline
\end{tabular}

Information:

- Not safe $=$ condition of relative availability of deficit and relative condition of inactive access

- Alert $=$ relative condition of deficit availability and relative conditions of good access and vice versa
- Safe $=$ relative conditions of availability of surpluses and relative conditions of good access

Research result shown in Table 5, that the combined relative conditions of rice availability and access to rice at the District level in Ogan Komering Ulu District shown that there was one District included in a safe position, West Baturaja District, and eight Districts included in the alert position were Sosoh Buay Rayap, Pengandonan, Ulu Ogan, Peninjauan, Sinar Peninjauan, Lubuk Batang, Lubuk Raja, and East Baturaja District, while four Districts included was the very unsafe position are Lengkiti, Muara Jaya, Semidang Aji and Kedaton Peninjauan Raya District. Some districts which are indicated to be in a food insecure condition must be a concern of the local government, so that in the future some sub-districts that are difficult to reach in order to be provided with ease in terms of access to food, including in terms of village road improvement. This result is consistent with finding from $[5,8]$.

\section{CONCLUSION AND RECOMMENDATION}

Mapping of Food Resilience Based on the Aspects of Food Access and Rice Availability in Ogan Komering Ulu District using three access indicators, Number of Occupational therapists, the working population of less than 15 hours in a week and the uneducated residents of primary education, it can be concluded as follows:

- The availability of rice indicates that at the district level in Ogan Komering Ulu, there were four districts which are surplus rice, Pengandonan, Ulu Ogan, Lubuk Batang, and West Baturaja District. While there were nine deficit districts, Lengkiti, Sosoh Buay Rayap, Muara Jaya, Semidang Aji, Peninjauan, Sinar Peninjauan, Lubuk Raja, East Baturaja, and the District of Kedaton Peninjauan Raya.

- The economic aspects of rice access at the district level in Ogan Komering Ulu shown that there were six districts in good condition, Sosoh Buay Rayap, Peninjauan, Sinar Peninjauan, Lubuk Raja, East Baturaja, and West Baturaja. While the other seven districts were in poor access, Lengkiti, Muara Jaya, Semidang Aji, Ulu Ogan, Lubuk Batang, and Kedaton Peninjauan Raya.

- The relative condition of rice availability and its access to rice at the district level in Ogan Komering Ulu District indicated that there was one district in the safe area, West Baturaja District.

In the future, it can be recommended for the government of Ogan Komering Ulu District, some districts which are indicated to be in a food insecure condition must be a concern of the local government, so that in the future some sub-districts that are difficult to reach in order to be provided with ease in terms of access to food, including in terms of village road improvement. 


\section{ACKNOWLEDGMENT}

We would like to express our gratitude to Research and Community Service Institution of Baturaja University for providing the required funding under the scheme of applied research grant.

\section{REFERENCES}

[1] BPS, Population Data. OKU District. Baturaja, 2016.

[2] G.A. Addibi, R. Wirosoedarmom and B. Suharto, "Food Security Mapping In Madiun Regency." Journal of Natural Resources and Environment, 2016.

[3] B.H. Sunarminto, Integrated Agriculture for Supporting National Food Sovereignty. Yogyakarta: BPFE, 2010.

[4] J.H. Mulyono, Sugiyarto and A.W. Widada, "Households' Food Security and Food Self Sufficiency in the Rural Marginal Area of Bojonegoro Regency," Jurnal Agro Ekonomi, vol. 26, no. 2, 2015.
[5] O. Wijaya, "Commodity Development Strategy Food Excellence in Supporting Food Security Region (Case Study in Batang District, Province Central Java)," Jurnal Agraris, vol. 3, no. 1, pp. 48-56, 2017.

[6] H. Malik, Removing Food Import Traps. Jakarta: LP3S, 2014.

[7] BPS, Population Data. OKU District. Baturaja, 2015.

[8] Y. Purwaningsih, Sutomo and N. Istiqomah, "Impact Transfer Analysis," Journal Agraris, vol. 1, no. 2, pp. 99-107, 2015.

[9] Y. Purwaningsih, Food Security: Situations, Issues, Policies, and Community Empowerment. Yogyakarta: Laksana, 2008.

[10] T. Susenas, "Food Security in Core Indonesia Problems And Alternative Solutions," Papers for ISEI Congress, Mataram, 2008.

[11] D.H. Darwanto, "Food Security Based on Farmer Production and Welfare," Agricultural Sciences, vol. 12, no. 2, pp. 152-164, 2005.

[12] S. Grasiana and T. Suardi, "Analysis Food Security Rice District Bangkinang," Journal Entry Agribusiness in Bangkinang Regency, Riau, 2011.

[13] W. Yuyun, Basic Statistics Descriptive. Jakarta: Medical Book, 2011.

[14] Munajat, "Analysis of Potential Food Plants in Ogan Komering Ulu Regency," Journal of Social Economics Agriculture, vol. VI, no. 2, 2014.

[15] Muslimah, S.H. Utomo and H. Sumarsono, "Analysis of Potential FoodProne Mapping Policy,” Jounal of Economic Social, vol. 6, no. 2, 2014 